PUBLIPRENEUR POLIMEDIA: JURNAL ILMIAH JURUSAN PENERBITAN

POLITEKNIK NEGERI MEDIA KREATIF

Vol.9, No. 1, Juni 2021 hal. 53-71

Submitted: 10 April 2021

Revised: 7 Mei 2021

Accepted: 15 Juni 2021

\title{
PROGRAM EVALUATION OF IMPLEMENTATION OF TECHNOLOGY, INFORMATION AND COMMUNICATION (ICT)-BASED LEARNING SYSTEMS IN MANAGEMENT PERSPECTIVE
}

\author{
Tipri Rose Kartika1 ${ }^{1 *}$ dan Jamaludin Malik ${ }^{2}$ \\ ${ }_{1}^{1}$ Politeknik Negeri Media Kreatif \\ 2Universitas Terbuka \\ E-mail: rosetipri@polimedia.ac.id¹, jamaluddinmalik2016@gmail.com²
}

\begin{abstract}
Information and Communication Technology (ICT) is currently one of the media in the learning process at various levels of education. Through ICT, the learning process in the classroom can be carried out properly, especially by educators (teachers) and students (students). Thus, ICT becomes the main tool for interacting learning regardless of space and time. Information technology-based learning information systems can present interesting and interactive learning models. In order for the application of learning information systems to give good results, optimization of the management function is needed in each stage of its development. The stages of the management function that are very familiar to stakeholders in the education sector consist of: Planning, Organizing, Actuating and Controlling (POAC). With this management function, the application of learning information systems will be built and implemented properly. To measure the success of the implementation of this system, an evaluation of this educational program is needed. One of the most frequently used program evaluation models is the program evaluation model, the program evaluation model developed by Stufflebeam (Stufflebeam's Model), also known as the CIPP Model. Madrasah Tsanawiyah (MTS) Mathlaul Anwar Lampung is one of the schools under the auspices of the Ministry of Religion which also uses information technology as a medium in learning. In its application, the management function becomes the basis for MTS Mathlaul Anwar in building an information technology-based learning system.
\end{abstract}

Keyword: Program Evaluation, Learning, Information and Communication Technology, POAC, CIPP Model

\section{EVALUASI PROGRAM PENERAPAN SISTEM PEMBELAJARAN BERBASIS TEKNOLOGI, INFORMASI DAN KOMUNIKASI (TIK) DALAM PERSPEKTIF MANAJEMEN}

\begin{abstract}
ABSTRAK
Teknologi informasi dan Komunikasi (TIK) dewasa ini menjadi salah satu media dalam proses pembelajaran diberbagai tingkatan pendidikan. Melalui TIK, proses pembelajaran dikelas dapat dilaksanakan dengan baik khususnya oleh pendidik (guru) dan peserta didik (siswa). Dengan demikian, TIK menjadi alat bantu utama berinteraksinya belajar tanpa mengenal ruang dan waktu. Sistem Informasi pembelajaran berbasis teknologi informasi dapat menyuguhkan model pembelajaran yang menarik dan interaktif. Agar penerapan sistem informasi pembelajaran memberikan hasil yang baik, dibutuhkan optimalisasi dari fungsi manajemen dalam setiap tahapan pembangunannya. Tahapan dari fungsi
\end{abstract}


manajemen yang sangat familier digunakan oleh para pemangku kepentingan bidang pendidikan terdiri dari: Planning, Organizing, Actuating dan Controlling (POAC). Dengan fungsi manajemen inilah penerapan sistem informasi pembelajaran akan dapat dibangun dan dilaksanakan dengan baik. Untuk mengukur sejauhmana keberhasilan dari penerapan sistemini dilaksanakan, dibutuhkan evaluasi terhadap program pendidikan ini. salah satu model evaluasi program yang sangat sering digunakan adalah model evaluasi program model evaluasi program yang dikembangkan oleh Stufflebeam (Stufflebeam's Model) juga dikenal dengan nama CIPP Model. Madrasah Tsanawiyah (MTS) Mathlaul Anwar Lampung merupakan salah satu sekolah dibawah naungan kementrian agama yang juga turut memanfaatkan teknologi informasi sebagai media dalam pembelajarannya. Pada penerapannya, fungsi manajemen menjadi landasan bagi MTS Mathlaul anwar dalam membangun Sistem pembelajaran berbasis teknologi informasi.

Kata kunci: Evaluasi Program, Pembelajaran, Teknologi Informasi dan Komunikasi , POAC, CIPP Model

\section{PENDAHULUAN}

Dewasa ini, teknologi informasi menjadi salah satu media terbaik yang dapat memberikan solusi dalam berbagai aktifitas kehidupan manusia diberbagai bidang. Salah satu bidang yang sangat bergantung pada teknologi informasi adalah bidang pendidikan. Hampir semua aktifitas atau kegiatan bidang pendidikan memanfaatkan teknologi informasi sebagai media utama dalam memberikan pelayanannya. Salah satu aktifitas penting pendidikan adalah pembelajaran.

Pembelajaran merupakan sarana berinteraksinya pendidik (guru) dengan peserta didik (siswa). Dengan mengoptimalkan sistem pembelajaran berbasis teknologi informasi, pembelajaran dapat dilaksanakan dengan berbagai bentuk kreatifitas yang menarik dan interaktif juga dalam ruang dan waktu yang tidak terbatas sehingga akan terwujud efesiensi dan efektifitas pembelajaran.

Ismail dan Ristati (2017:294) menyebutkan “Organisasi pendidikan merupakan, salah satu institusi yang banyak mendapatkan manfaat besari dari Pemanfaatan teknologi informasi dalam pembelajaran beberapa manfaat yang dapat dirasakan adalah sebagai berikut: Tersedianya pengelolaan data dan informasi pendidikan. Selanjutnya adanya integrasi data dan informasi pendidikan juga mendukung pengambilan keputusan (Horwath dkk, 2006).

Dalam dunia pendidikan, sudah banyak yang memanfaatkan sistem pembelajaran berbasis teknologi informasi informasi manajemen pendidikan untuk mendukung proses pembelajaran. Baik itu lembaga pendidikan dasar, lembaga pendidikan tingkat menengah, maupun lembaga pendidika tingkat tinggi (perguruan tinggi). Ketika mengoptimalkan fungsi teknologi informasi diharapkan dapat meningkatkan pola pikir dan kreatifitas pendidik (guru) dan peserta didik (siswa) serta masyarakat terus berkembang dan meningkat". Rochaety (2006:15)

Salah satu lembaga pendidikan yang menjadikan teknologi informasi sebagai mendia pembelajaran adalah MTS Mathlaul Anwar Sidomulyo Lampung Selatan Lampung. Penerapan sistem informasi pembelajaran berbasis teknologi informasi merupakan program strategis yang dijalankan MTS Mathlaul Anwar setidaknya dalam empat semester (dua tahun) terakhir dengan menyertakan berbagai pihak khususnya pihak-pihak yang ada didalam sekolah (internal sekolah). Penerapan teknologi informasi ini diharapkan dapat meningkatkan mutu 
layanan pembelajaran baik bagi guru maupun siswa yang pada akhirnya dapat meningkatkan mutu SDM guru dan siswa.

Penerapan teknologi informasi pembelajaran ini dimulia dari perencanaan dengan membuat agenda pembangunan sistem informasi pembelajaran dimulai dari pembuatan visi misi, dan maksud dan tujuan (target yang ingin dicapai). Tahapan selanjutnya pembentukan Tim TI berikut tugas dan tanggungjawabnya. Selanjutnya Tim TI membuat jadwal implementasi pembanguan Sistem Pembelajaran berbasis Teknologi Informasi, melakukan inventarisasi sumber daya manusia, perlengkapan dan peralatan yang dibutuhkan, Pembanguan Sistem Pembelajaran Berbasis Teknologi Informasi dan Komunikasi (TIK), pembuatan Standar Operasional Prosedur (SOP) Penggunaan Media Pembalajaran berbasis TIK, sosialisasi dan pelatihan penggunaan Sistem Informasi pembelajaran berbasis teknologi informasi (TIK), bagi guru dan sosialisasi ke siswa.

Implementasi sistem informasi pembelajaran berbasis teknologi informasi merupakan tahapan selanjutnya yang dilaksanakan oleh guru dan siswa khususnya diruang kelas. Guru sebagai user dalam menggunakan media pembelajaran berbasis teknologi informasi dan komunikasi (TIK) dengan megacu pada standar operasional prosedu (SOP) yang telah dibuat oleh Tim IT. Pengawasan merupakan tahapan terakhir dari fungsi manajamen yang dilakukan oleh kepala sekolah/wakil kepala sekolah terhadap jalannya pelaksanaan sistem informasi pembelajaran berbasis teknologi informasi.

Pada tahapan ini kepala sekolah/wakil kepala sekolah bersama sama dengan Tim IT menganalisa dan meneliti pelaksanaan pembelajaran berbasis teknologi informasi baik dari sisi sistem informasinya, teknologi informasinya maupun kualitas yang dihasilkan dari implementasi teknologi informasi pembelajaran ini. dengan pengawasan ini diharapkan dapat diketahui sejauhmana kesuksesan dari penerapannya terutama dalam hal layanan pembelajaran guna meningkatkan mutu SDM Guru dan Mutu SDM Siswa.

Evaluasi program menggunakan CIPP Model (Stufflebeam's Model) terhadap penerapan program pendidikan ini sudah banyak dilakukan oleh para peneliti dan akademisi, beberapa diantaranya adalah Penelitian tentang "Evaluasi Program Mutu Berbasis Sekolah (MMBS) di SMAN 61 Unggulan Jakarta Timur (Pendekatan Evaluasi Berdasarkan Model CIPP)". Penelitian ini dilakukan oleh Supandi pada tahun 2017. (Supadi, 2017). Selanjutnya penelitian yang dilakukan oleh Mukhlisin (2015), dalam desertasinya berjudul "Sistem Informasi Manajemen Berbasis Teknologi Informasi dan Komunikasi Dalam Peningkatan Mutu Layanan Pendidikan dan Latihan Profesi Guru (PLPG), (Studi Kasus Pada MTsN 1, MTsN 2, MTs Pancasila di Lingkungan Kementrian Agama Kota Bengkulu)" pada program Pasca sarjana Universitas Islam Nusantara Bandung 2015. (Mukhlisin, 2015).

Penelitian yang dilakukan oleh Abna Hidayati pada tahun 2010, ia meneliti tentang "Evaluasi Pemanfaatan Program Menggunakan Model CIPP Pada Sekolah Menengah". (Di \& Mariana, 2013). Sementara Yoga Budi Bhakti melakukan penelitiannya tentang "Evaluasi Program Model CIPP Pada Proses Pembelajaran IPA SMP IT Raudlatul Jannah Gatam, Banjarwangi, Ciawi Bogor". (Bhakti, 2017). Terakhir peneliti menemukan penelitiannya Nova Indah Wijayanti, dkk pada tahun 2019 dengan mengusung tema “Evaluasi Program Pendidikan Pemakai Dengan Model CIPP di Perpustakaan Fakultas Teknik UGM". (Wijayanti DKK, 2019). 


\section{METODE PENELITIAN}

Implementasi penelitian ini, memakai penelitian dengan metode kualitatif. Musfikon (2012:12) menafsirkan "Penelitian kualitatif yaitu penelitian yang dilakukan untuk melihat fenomena yang terjadi pada subjek penelitian seperti persepsi, sikap, motivasi, perilaku, tindakan, dll. Penelitian ini dilakukan secara holistic, dan dideskripsikan melalui rangkaian kalimat yang dimengerti pada suatu ruang khusus yang berjalan alamiah dengan menggunakan metode yang alamiah pula". (Musfiqon., 2012).

Sugiyono

memaparkan:

"Penelitian kualitatif dimaknai sebagai metode penelitian yang berdasarkan filsafat post positivisme, penelitian ini, dipakai untuk menelaah penelitian pada keadaan obyek yang bersifat alamiah. Dalam hal ini peneliti bertindak sebagai kunci utama dalam suksesnya sebuah penelitian, sementara itu, sampel yang merupakan sumber data yang diambil dapat dilakukan secara purposive atau snowball, teknik pengumpulan dilakukan dengan trianggulasi (gabungan), analisis data besifat induktif atau kualitatif, dan hasil penelitian kualitatif lebih menekan kan mkna dari pada generalisasi". (Sugiyono, 2011)

Dalam megakomodir data dan informasi, penelitian kualitatif ini dilakukan dengan menerapkan teknik dan instrumen sesuai dengan data dan informasi yang diinginkan dalam penelitian. Sugiyono (2011:308) menyebutkan: "Ada beberapa teknik yang dapat digunakan peneliti untuk mengumpulkan data penelitian, diantaranya: a) teknik observasi; b) wawancara; c) teknik dokumentasi; e) triangulasi". (Sugiyono, 2011). Data dan informasi yang diperoleh dari sumber responden penelitian akan memiliki makna yang berarti bila dilanjutkan dengan kegiatan analisis terhadap data dan informasi.
Hasil analisa dan Kajian akan data yang telah dikumpulkan ketika melakukan penelitian. Hal ini dimaksudkan apabila ada data dan informasi yang kurang atau tidak sesuai maka dengan mudah dapat dipenuhi. Untuk menganalisis data peneliti ini perlu ditempuh beberapa prosedur. Adapaun prosedur analisis data yang ditempuh dalam penelitian ini didasarkan pada pendapat Nasution (1992:129) yaitu: melakukan reduksi terhadap data; menampilkan data; memberikan kesimpulan dan melakukan verifikasi dan filterasi terhadap data". (Nasution, 1992)

Pendekatan kualitatif dalam penelitian ini digunakan untuk mendeskripsikan dan menganalisis tentang Penerapan Sistem Informasi Pembelajaran Berbasis Teknologi informasi dan Komunikasi (TIK) Dalam Perspektif Manajemen Pada MTS Mathlaul Anwar Lampung. Kemudian pendekatan kualitatif yang digunakan dalam penelitian ini, data dan informasi yang diperoleh selanjutnya diorganisir dan dianalisis untuk mendapatkan gambaran tentang Penerapan Sistem Informasi pembelajaran berbasis teknologi informasi bagi guru dan siswa di MTS Mathlalul Anwar Lampung.

\section{HASIL DAN PEMBAHASAN}

Pembahasan tentang penerapan sistem pembelajaran berbasis teknologi informasi dan komunikasi (TIK) pada MTS Mathlaul Anwar yang berlokasi di Jl.Slamet Riyadi No.02 Sidorejo, Sidorejo, Kecamatan Sidomulyo Kabupaten Lampung Selatan, berdasarkan hasil penelitian selama dua bulan (januari-februari 2021) yang bersumber dari wawancara dengan dengan kepala sekolah, wakil kepala sekolah, Tim IT, Guru, Siswa dan Komite Sekolah dan obervasi serta hasil studi dokumentasi diuraikan sebagai berikut:

\section{Hasil Penelitian Pada Tahap Perencanaan (Planning) Penerapan Sistem Pembelajaran Berbasis}


Teknologi Informasi dan Komunikasi (TIK) Pada MTS Mathlaul Anwar Lampung.

Tahapan perencanaan dimulai pada bulan januari tahun 2018 dengan dilaksanakannya rapat rencana penerapan teknologi informasi dan komunikasi (TIK) dalam proses pembelajaran. Rapat tersebut dipimpin oleh kepala sekolah yang dihadiri oleh wakil kepala sekolah, bagian operator, guru dan komite sekolah. Rapat yang dilaksanakan menghasilkan berbagai keputusan dan kesepakatan diantaranya disepakati akan diterapkan TIK pada proses pembelajaran dikelas. Selanjutnya dalam waktu satu minggu, kepala sekolah bersama-sama dengan wakil kepala sekolah merumuskan mengenai visi misi, maksud dan tujuan penerapan TIK dalam proses pembelajaran tersebut. Adapun visi yang telah dirumuskan dari penerapan TIK dalam proses pembelajaran adalah "Mewujudkan MTS Unggul Berbasis Teknologi Informasi di tahun 2025". Sementara yang menjadi semangat misinya adalah: 1). Mewujudkan Layanan Pembelajaran Unggul berbasis Teknologi Informasi dan Komunikasi, 2) Mewujudkan SDM Unggul dibidang Teknologi Informasi dan Komunikasi (TIK), 2) Mewujudkan Siswa Unggul dibidang Teknologi Informasi dan Komunikasi (TIK). Selanjutnya hasil rumusan dari maksud dan tujuan dari pembangunan Sistem pembelajaran berbasis TIK ini adalah sebagai berikut: 1). Menjadikan Pembelajaran yang menarik dan menyenangkan, 2). Melakukan komunikasi yang lebih aktif dan interaktif menggunakan media visual, 3). Menyediakan sarana pembelajaran yang baik, kondusif dan lengkap, 4) Meningkatkan kapasitas SDM Guru dan Siswa dibidang Teknologi Informasi dan Komunikasi
(TIK) dan 5). Menyediakan referensi pembelajaran yang lengkap dan terpadu.

2. Hasil Penelitian Pada Tahap Pengorganisasian (Organizing) Penerapan Sistem Pembelajaran Berbasis Teknologi Informasi dan Komunikasi (TIK) Pada MTS Mathlaul Anwar Lampung.

Pada Tahapan pengorganisasian, hasil temuan dilapangan kegiatan yang dilakukan oleh Kepala Sekolah adalah pembentukan Tim IT. Mengingat ketersediaan Sumber Daya Manusia (SDM) yang kurang, maka Kepala sekolah memberdayakan Guru mata pelajaran komputer dan Operator Sekolah ditunjuk sebagai Tim yang membangun Sistem Pembelajaran berbasis TIK. Tim ini dikenal dengan nama Tim TI (Teknologi Informasi). Dengan Surat Tugas (ST) yang dibuat oleh Kepala Sekolah, Tim TI dalam tahap pengorganisasian ini mempunyai tugas utama sebagai berikut:

- Pembuatan jadwal Implementasi. Jadwal Implementasi adalah agenda yang dibuat oleh Tim TI dari mulai perencanaan pembangunan TIK, Pengorganisasian TIK, Penerapan TIK sampai dengan Pengawasan terhadap implementasi TIK dalam proses pembelajaran. Jadwal implementasi inilah yang menjadikan pedoman bagi Tim TI kapan pembangunan TIK dimulai, apa saja yang harus dikerjakan dalam setiap harinya dan kapan Pembangunan TIK selesai dikerjakan dan diimplementasikan dalam proses pembelajaran dikelas.

- Optimalisasi sumber daya manusia (SDM); pada tahap ini Tim TI melengkapi personil dengan merekrut beberapa orang yang familier dengan teknologi informasi, diantaranya adalah: 
operator sekolah, staff TU, dan guru. Kesemua personil tersebut diberikan tugas dan tanggungjawab masing-masing seperti bagian penyediaan database sekolah, bagian inventarisir data dan dokumen, bagian input database, bagian instalasi jaringan komputer, bagian pembelian barang, bagian desain materi pelajaran menggunakan microsoft power point dan bagian lainnya.

- Melakukan inventarisasi perlengkapan dan peralatan yang dibutuhkan; pada tahap ini Tim TI membuat surat permohonan kepada kepala sekolah berkenaan dengan berbagai barang (perlengkapan dan peralatan) yang dibutuhkan. Adapun berbagai barang yang diajukan seperti: 10 unit komputer, 10 unit LCD Projector, 10 Unit Sound System, Pembelian Software untuk pembelajaran, dan berbagai peralatan dan perlengkapan pendukung lainnya.

- Melakukan pembanguan Sistem Pembelajaran Berbasis Teknologi Informasi dan Komunikasi (TIK). Pada tahap ini Tim TI melakukan pembangunan sistem pembelajaran berbasis teknologi informasi selama tiga bulan. Kegiatan ini dimulai dari instalasi hardware dan software, instalasi jaringan komputer, instalasi media belajar lainnya seperti sound system, lcd projector, dll.

- Melakukan testing terhadap hasil pembangunan sistem pembelajaran berbasisi teknologi informasi dan komunikasi (TIK). Testing dilakukan sebagai upaya untuk meminimalisir berbagai kesalahan dan kekurangan yang akan terjadi. Testing ini melibatkan guru dan siswa agar dapat diketahui berbagai kendala dari implementasi sistem pembelajaran berbasis teknologi informasi dimasa yang akan datang.

- Pembuatan Standar Operasional Prosedur (SOP) Penggunaan Media Pembalajaran berbasis TIK. SOP ini dibuat sebagai pedoman bagi para guru dan siswa dalam mengoptimalisasi peran teknologi informasi yang diterapkan dalam proses pembelajaran.

- Sosialisasi dan pelatihan penggunaan Sistem Informasi pembelajaran berbasis teknologi informasi (TIK), bagi guru dan sosialisasi ke siswa.

3. Hasil Penelitian Pada Tahap Pelaksanaan (Actuating) Penerapan Sistem Pembelajaran Berbasis Teknologi Informasi dan Komunikasi (TIK) Pada MTS Mathlaul Anwar Lampung.

Hasil penelitian atas penemuan dilapangan pada tahapan pelaksanaan penerapan sistem pembelajaran berbasis teknologi informasi dan komunikasi (TIK) ini, beberapa kegiatan yang dilakukan oleh Tim TI adalah:

- Melaksanakan pelatihan Penerapan Sistem Pembelajaran Berbasis Teknologi Informasi dan Komunikasi (TIK) kepada guru yang akan menggunakan dan memanfaatkan TIK sebagai media pembelajaran.

- Melakukan sosialisasi Penerapan Sistem Pembelajaran Berbasis Teknologi Informasi dan Komunikasi (TIK) kepada siswa yang akan menerima atau menjadi pengguna media pembelajaran dikelas.

- Mensosialisasikan Standar Operasional Prosedur (SOP) tentang penggunaan TIK Pembelajaran kepada guru dan siswa. 
- Memasang seluruh media pembelajaran berbasis TIK diruang kelas.

- Memberikan simulasi penggunaan media pembelajaran berbasis TIK diruang kelas

Selanjutnya pada tahap implementasi ini, guru sebagai pengguna utama Penerapan Sistem Pembelajaran Berbasis Teknologi Informasi dan Komunikasi (TIK) melaksanakan tugas pengajarannya menggunakan fasilitas TIK diruang kelas. Dengan berpedoman pada Standar Operasional Prosedur (SOP), guru menggunakan media pembelajaran ini sebagai upaya untuk merealisasikan visi, misi, maksud dan tujuan dari penerapan TIK Pembelajaran yang telah dicanangkan bersama. Kurikulum pembelajaran dan berbagai materi pembelajaran sudah disiapkan seluruhnya dan sudah didesain oleh Tim TI didalam Teknologi Informasi dan Komunikasi (TIK) ada yang dalam bentuk slide microsoft power point ada dalam bentuk pdf dan dalam bentuk software lainnya. Sementara itu, selain materi pembelajaran yang sudah lengkap seluruhnya, didalam TIK ini juga disediakan ruang pembuatan berita acara pembelajaran, ruang absensi yang berbasis jaringan (Intranet) oleh Tim TI untuk absensi guru dan siswa, sehingga proses pembelajaran diharapkan semaikn efektif dan efisien. Pada tahap implementasi ini, apabila guru membutuhkan tambahan materi, dengan sangat mudah seorang guru dapat mencari dan menemukannya didalam ruang maya (internet), mengingat teknologi informasi dan komunikasi (TIK) yang disediakan selain berbasis intranet juga berbasis internet. Pelaksanaan Penerapan Sistem Pembelajaran Berbasis Teknologi Informasi dan Komunikasi (TIK) diharapkan dapat memudahkan pendidik (guru) dan peserta didik (siswa) dalam membangun komunikasi dan interaksi yang baik. Dengan Penerapan Sistem Pembelajaran Berbasis Teknologi Informasi dan Komunikasi (TIK) hasil akhir yang diinginkan adalah terwujudnya SDM guru dan SDM Siswa yang unggul berbasis teknologi informasi dan komunikasi (TIK). Dengan Penerapan Sistem Pembelajaran Berbasis Teknologi Informasi dan Komunikasi (TIK) juga diharapkan dapat meningkatkan mutu layanan pembelajaran khususnya diruang kelas.

Sementara siswa yang membawa laptop dapat, selain dapat milhat materi melalui layar LCD Projector, juga dapat membukanya didalam laptop sendiri mengingat materi dapat dicopy oleh siswa. Sehingga memudahkan siswa untuk mempelajari materi pembelajaran baik yang sudah, sedang atau belum diajarkan. Siswa juga dapat memperbaharui materinya jika terdapat perbaikan materi atau penambahan materi daro guru. Dalam kegiatan pelaksanaan penerapan media pembelajaran berbasis teknologi informasi dan komunikasi (TIK) ini, Tim TI juga turut mensupport berbagai permintaan atau kebutuhan dari guru, misalnya jika terdapat kekurangan atau kesalahan dalam penulisan materi pembelajaran. Pada tahapan fungsi manajemen pelaksanaan ini, kegiatan yang paling utama adalah berlangsungnya kegiatan pembelajaran dikelas oleh guru yang dilaksanakan setiap hari belajar. Guru tidak lagi membawa banyak referensi dalam bentuk manual, mengingat berbagai referensi terbaru dapat dengan mudah diakses melalui jaringan internet yang tersedia pada komputer kelas. 


\section{Hasil Penelitian Pada Tahap Pegawasan (Controlling) Penerapan Sistem Pembelajaran Berbasis Teknologi Informasi dan Komunikasi (TIK) Pada MTS Mathlaul Anwar Lampung.}

Pada Tahapan fungsi manajemen terakhir ini, kegiatan yang dilakukan oleh kepala sekolah, wakil kepala sekolah dan Tim TI adalah memantau jalannya pelaksanaan penerapan sistem pembelajaran berbasis teknologi informasi dan komunikasi (TIK) dikelas. Secara berkala kepala sekolah, wakil kepala sekolah dan Tim TI melakukan pemantauan kedalam ruangan kelas, untuk melihat sejauhmana efektifitas dan efesiensi penerapan media pembelajaran ini dapat dijalankan oleh guru dan siswa. Beberapa hal penting yang dilakukan oleh kepala sekolah dan wakil kepala sekolah diantaranya adalah sebagai berikut:

- Pemantauan proses pembelajaran menggunakan media pembelajaran TIK didalam kelas

- Menghimpun berbagai keluhan dan masukan dari guru dan siswa tentang penerapan media pembelajaran berbasis TIK dikelas.

- Melakukan komunikasi dengan guru dan siswa tentang sejauhmana efektifitas dan efesiensi penerapan media pembelajaran berbasis TIK dikelas

- Melakukan pendataan terhadap berbagai keluhan dan masukan dari guru dan siswa tentang penerapan media pembelajaran berbasis TIK dikelas

- Melakukan analisa dan penilaian terhadap sejauhmana keberhasilan pembelajaran berbasis TIK didalam kelas terutama terhadap peningkatan mutu layanan pembelajaran, mutu sdm guru dan mutu sdm siswa.
- Melakukan analisa dan penilaian terhadap siswa, sejauhmana peningkatan prestasi siswa dapat tercapai dengan pemberlakuan media pembelajaran berbasis TIK didalam kelas.

- Membuat laporan penilaian terhadap pelaksanaan penerapan media pembelajaran berbasis TIK dikelas. Laporan penilaian terdiri dari: laporan atas peningkatan mutu layanan pembelajaran berbasis TIK, laporan atas peningkatan mutu SDM guru berbasis TIK, Laporan atas peningkatan mutu SDM Siswa.

Demikian hasil temuan penelitian atas pelaksanaan tahap pengawasan yang dilakukan oleh kepala sekolah, wakil kepala sekolah dan Tim TI.

Merujuk pada model evaluasi program model evaluasi program yang dikembangkan oleh Stufflebeam (Stufflebeam's Model) juga dikenal dengan nama CIPP Model. Peneliti memberikan evaluasi terhadap pelaksanaan penerapan Sistem Pembelajaran Berbasis Teknologi Informasi dan Komunikasi (TIK) Pada MTS Mathlaul Anwar Lampung dalam perspektif fungsi manajemen menurut Terry adalah sebagai berikut:

1. Evaluasi Konteks (Context Evaluatioan) Terhadap Penerapan Sistem Pembelajaran Berbasis Teknologi Informasi dan Komunikasi (TIK) Pada MTS Mathlaul Anwar Lampung.

Evaluasi konteks sangat dibutuhkan untuk mengetahui seberapa besar potensi kekuatan dan berbagai kelemahan yang dimiliki sekolah. kekuatan dan kelemahan yang telah diketahui akan menjadikan seorang evaluator mampu memberikan arah perbaikan yang diperlukan. Dalam konteks pendidikan, Sudjana dan Ibrahim dalam Ananda R, Rafida T (2017:48) menerjemahkan evaluasi 
masukan menyangkut sarana, modal, bahan, dan rencana strategi yang ditetapkan untuk mencapai tujuan pendidikan, komponen input meliputi siswa, guru, desain, saran, dan fasilitas. Sebagai evaluator, pada evaluasi konteks ini, peneliti melihat bahwa sangat penting kepala sekolah dan wakil kepala sekolah sebelum menerapkan media pembelajaran berbasis TIK inimelakukan analisis SWOT (Strength, Weakness, Opportunity and Threat). Analisis SWOT dilakukan untuk mengetahui secara medalam kekuatan dan kelemahan sekolah serta melihat peluang dan ancaman yang mungkin terjadi. Analisis ini dirancang sebagai langkah awal sebelum sebuah kebijakan atau keputusan dilaksanakan dan tentunya sebagai sebuah rencana staretegis sebuah sekolah. Beberapa Faktor SWOT yang dapat dilakukan terhadap penerapan media pembelajaran berbasis Teknologi informasi dan komunikasi (TIK) di MTS Mathlaul Anwar Lampung adalah sebagai berikut:

- Faktor Internal (Kekuatan) yang dimiliki antara lain: Kemampuan SDM Sekolah, SDM Lulusan Yang dihasilkan, Bentuk Pelayanan yang diberikan, Sarana dan Prasarana yang tersedia, Media Pembelajaran yang dilaksanakan

- Faktor Internal (Kelemahan) yang dimiliki antara lain: Kurangnya SDM Sekolah, Bentuk Pelayanan yang Kurang, SDM Lulusan Yang belum sesuai yang diharapkan, Sarana dan prasarana yang kurang, Media pembelajaran yang kurang, Posisi keuangan yang kurang memadai

- Faktor Eksternal (Peluang) yang dimiliki antara lain: Terdapatnya Sekolah lanjutan yang berbasis pesantren, Terdapatnya sekolah lanjutan yang bertaraf internasional, Berpeluang menjadi Sekolah Unggulan berbasis TIK, Berpeluang meluluskan SDM Unggul berbasis TIK, Berpeluang menjadi MTS bertaraf Internasional

- Faktor Eksternal (Ancaman) yang dimiliki antara lain: Terdapatnya MTS yang terlebih dahulu menerapkan media pembelajaran berbasis TIK, Berpotensi masuknya cyber crime (kejahatan dunia maya), Berpotensi masuknya informasi yang tidak benar (hoax)

Dari keempat faktor SWOT diatas, peneliti membagi kedalam dua analisis yaitu Analisis Lingkungan Internal (ALI) dan Analisis Lingkungan Ekternal (ALE). Analisis Lingkungan Internal (ALI) terhadap penerapan media pembelajaran berbasis TIK di MTS Mathlaul Anwar Lampung ini dengan mencermati dan mengidentifikasi kondisi-kondisi internal sekolah baik unsur kekuatan (strength) maupun unsur kelemahan (weakness). Adapun hasil pencermatan dan identifikasi terhadap Analisis Lingkungan Internal (ALI) pada MTS Mathlaul Anwar Lampung dijabarkan secara singkat sebagai berikut:

- Kemampuan SDM Sekolah. Jumlah karyawan khususnya guru mata pelajaran sudah sangat terpenuhi, dan mereka selain sudah berpengalaman dalam mengajar juga hampir seluruhnya sudah bersertifikasi pendidik. namun disisi lain kelemahannya adalah kemampuan SDM guru terhadap teknologi informasi dan komunikasi (TIK) sangat minim. Ditemukan hanya dua orang saja yang dikategorikan terampil mengoperasikan Teknologi informasi dan Komunikasi (TIK), hal inilah yang wajib menjadi perhatian sekolah dalam menyediakan/merekrut SDM yang 
terampil dibidang Teknologi informasi dan komunikasi (TIK) agar penerapan media pembelajaran berbasis TIK dapat diimplementasikan diruang belajar.

- Analisa terhadap SDM lulusan yang dihasilkan. Lulusan dari MTS Mathlaul Anwar lampung cukup mumpuni terutama pada bidang keagamaan. Kurikulum yang diberikan sangat kolaboratif dan variatif. Selain kurikulum yang telah digariskan kementrian agama (kemenag) juga kurikulum pesantren salafi menjadi salah satu fokus dalam pembelajarannya, inilah yang menjadi keunggulan dari lulusan MTS Mathalun Anwar Lampung. Namun disisi lain kelemahannya adalah pemahaman dan keterampilan dibidang Teknologi Informasi (TIK) sangat minim. Materi yang berhubungan dengan TIK hanya diberikan sebagai pemenuhan kewajiban kurikulum saja, sehingga banyak lulusan yang masih awam dengan teknologi informasi dan komunikasi.

- Analisis terhadap bentuk pelayanan yang diberikan. Sebagai sekolah yang berada dibawah naungan kementrian agama dan sekolah yang berbasis pesantren tentu mempunyai keunggulan dari sisi sikap dan akhlak, berbagai pelayanan diberikan kepada warga belajar, warga sekolah dan masyarakat dengan penuh sikap dan akhlak yang terpuji baik dalam hal pelayanan administrasi sekolah, pelayanan pembelajaran dan pelayanan lainnya. Namun demikian sangat disayangkan bentuk pelayanan yang baik itu tidak didukung dengan teknologi informasi dan komunikasi sehingga dalam prosesnya berbagai bentuk pelayanan yang diberikan terlihat lambat dan tidak terdatabase dengan baik.

- Fasilitas sarana yang tersedia. Dari sisi sarana dan prasarana sebagai sekolah swasta, MTS Mathlaul Anwar Lampung terbilang cukup tersedia, dengan berbagai bantuan dari pemerintah, swasta dan pengelolaan manajemen dan keuangan yang baik, MTS ini dapat menyediakan sarana prasarana yang memadai. Ketersediaan yang ada saat ini sangatlah jauh dari harapan, oleh karenanya dibutuhkan penambahan dan perbaikan sarana dan prasarana sekolah disana sini.

- Media Pembelajaran yang dilaksanakan. Dalam menerapkan media pembelajaran berbasis TIK dibutuhkan media pembelajaran yang memadai. Untuk tataran Sekolah tingkat SMP didaerah, MTS Mathlaul Anwar Lampung termasuk kedalam sekolah yang cukup baik dalam menerapkan media pembelajaran berbasis TIK diruang kelas. Namun demikian kelemahannya adalah, belum tercukupinya media pembelajaran berbasis TIK disemua ruang belajar/ruang kelas. Selanjutnya media pembelajaran yang tersedia dari sisi kapasitas dan konfigurasinya masih belum sesuai dengan yang diharapkan.

- Analisis terhadap kemampuan sekolah dari sisi keuangan. Hal ini perlu ditingkatkan, sekolah harus melakukan peningkatan pendapatan baik melalui kenaikan iuran sekolah, sumbangan dari orangtua/wali siswa, sumbangan dari perorangan atau institusi/organisasi/perusahaan yang peduli dengan pendidikan, kerjasama dengan pihak lain dan atau usaha sekolah misalnya dalam 
bentuk koperasi dapat diciptakan. Kondisi anggaran atau keuangan sangat mempengaruhi sukses tidaknya penerapan media pembelajaran berbasis TIK pada sebuah lembaga pendidikan.

Sementara Analisis Terhadap Lingkungan Eksternal (ALE) berupa pencermatan dan identifikasi terhadap kondisi lingkungan di luar organisasi (sekolah) MTS Mathlaul Anwar Lampung baik berupa Peluang (Opprotunity) maupun berupa ancaman (Threat) dapat dijabarkan sebagai berikut: Peluang untuk melanjutkan pendidikan ke jenjang SMA/SMK/MA/MAK khususnya diwilayah lampung selatan sangatlah besar, mengingat sangat banyak sekolah tingkat menengah atas tersedia didaerah tersebut. Sekolah-sekolah tersebut baik yang berbasis pesantren maupun yang bertaraf rintisan internasional. Rencana penerapan media pembelajaran berbasis TIK ini juga merupakan jawaban atas visi misi sekolah untuk menjadi sekolah unggulan berbasis TIK diwilayah lampung.

Selain itu MTS Mathlaul anwar berpeluang meluluskan SDM yang unggul dibidang Teknologi informasi dan komunikasi (TIK). Terdapatnya MTS yang terlebih dahulu menerapkan media pembelajaran berbasis TIK. Peluang yang ada tentu saja terkendala dengan berbagai ancaman yang mungkin terjadi, diterapkannya media pembelajaran berbasi teknologi informasi dan komunikasi (TIK) disekolah berpotensi masuknya cyber crime (kejahatan dunia maya) dan berpotensi masuknya informasi yang tidak benar (hoax).

Dari hasil analisis SWOT diatas, evaluasi konteks terhadap penerapan media pembelajaran berbasis teknologi informasi dan komunikasi di MTS Mathlaul Anwar Lampung perlu dievaluasi sehingga dalam melaksanakan kegiatan fungsi manajemen akan selalu berpedoman pada hasil analisis SWOT diatas. Beberapa hal yang perlu dievaluasi seperti perbaikan atau penyempurnaan visi, misi, maksud dan tujuan penerapan media pembelejaran berbasis TIK, dibuatkannya rencana strategis (strategic planning) dan nilai strategis (Value strategic) yang akan dicapai dari penerapan media pembelajaran berbasis TIK, evaluasi terhadap kesiapan sarana dan prasarana, ketersediaan perlengkapan dan peralatan, evaluasi terhadap ketersediaan SDM khususnya yang memahami dan terampil dibidang TIK, evaluasi terhadap kemampuan keuangan dalam pengembangan media pembelajaran berbasis TIK kedepan.

\section{Evaluasi Masukan (Input Evaluatioan) Terhadap Penerapan Sistem Pembelajaran Berbasis Teknologi Informasi dan Komunikasi (TIK) Pada MTS Mathlaul Anwar Lampung.}

"evaluasi masukan sangat membantu dalam pemecahan masalah untuk pengambilan sebuah keputusan, juga berfungsi untuk memilih dan menentukan sumber daya yang dbutuhkan, alternatif atau pilihan apa yang harus diambil, bagaimana perencanaan strategis dalam mencapai target, menentukan metode/prosedur dan mekanisme kerja untuk mencapainya. Pertanyaan-pertanyaan terkait dengan masukan mengarah pada pemecahan masalah yang mendorong diselenggarakannya sebuah program. Dalam hal ini komponen evaluasi masukan meliputi: a) sumber daya manusia, b) sarana dan peralatan pendukung, c) dana atau anggaran, dan d) berbagai prosedur dan aturan yang diperlukan". Stufflebeam dalam Ananda R., Rafida T (2017:45-49). Dalam konteks pendidikan, Sudjana dan Ibrahim dalam Ananda R, Rafida T (2017:48) 
menerjemahkan "evaluasi masukan menyangkut modal, strategi, bahan, dan sarana yang ditentukan dalam mewujdukan tujuan pendidikan. komponen input meliputi siswa, guru, desain, saran, dan fasilitas".

Merujuk pada landasan teori diatas, evaluasi masukan terhadap Penerapan Media Pembelajaran Berbasis Teknologi Informasi dan Komunikasi (TIK) di MTS Mathlaul Anwar Lampung dapat dijabarkan sebagai berikut:

- Ketersediaan SDM. Berdasarkan temuan penelitian dan evaluasi konteks terhadap Penerapan Media Pembelajaran Berbasis Teknologi Informasi dan Komunikasi (TIK) di MTS Mathlaul Anwar Lampung, maka pihak sekolah yang dalam hal ini kepala sekolah, wajib melakukan rekrutmen terhadap SDM yang ahli dan berpengalaman dibidang Sistem dan Teknologi informasi. Kualifikasi yang harus direkrut diantaranya adalah SDM yang menguasai perancangan sistem untuk ditempatkan sebagai analys system, SDM yang menguasai bahasa pemrograman komputer untuk ditempatkan sebagai programmer. SDM yang menguasai perangkat keras dan jaringan komputer yang akan ditempatkan menjadi Teknisi Komputer/IT Support/Netwroking Support, SDM yang menguasai pengelolaan database yang akan ditempatkan menjadi database administrator. SDM yang menguasai bidang desain grafis untuk ditempatkan menjadi seorang desainer. Selanjutnya SDM yang menguasai bidang akuntansi untuk ditempatkan pada bagian keuangan dan SDM-SDM lainnya yang dibutuhkan. Inilah yang nantinya akan menjadi Tim IT dalam penerapan media pembelajaran berbasis TIK di MTS Mathlaul Anwar Lampung.

- Ketersediaan sarana dan prasarana. Ruang belajar yang mencukupi dan memadai wajib menjadi perhatian khusus dalam Penerapan Media Pembelajaran Berbasis Teknologi Informasi dan Komunikasi (TIK) di MTS Mathlaul Anwar Lampung. Ruang belajar yang luas dan kondusif, meja dan kursi belajar yang memadai serta ruangan belajar (kelas) menggunakan AC merupakan sebuah keharusan dalam Penerapan Media Pembelajaran Berbasis Teknologi Informasi dan Komunikasi (TIK) di MTS Mathlaul Anwar Lampung. Cepat rusaknya media pembelajaran berbasis TIK juga dipengaruhi oleh ketersediaan sarana yang kurang memadai. Ketersediaan media pembelajaran seperti komputer dan peralatan serta perlengkapan pendukungnya, ketersediaan LCD Projector dan ketersediaan sound system yang memadai juga dapat menentukan sukses tidaknya Penerapan Media Pembelajaran Berbasis Teknologi Informasi dan Komunikasi (TIK) di MTS Mathlaul Anwar Lampung.

- Modal (Keuangan) yang mencukupi. Sarana yang memadai, ketersediaan SDM yang ditunjang dengan anggaran. Oleh karena itu, dalam Penerapan Media Pembelajaran Berbasis Teknologi Informasi dan Komunikasi (TIK) di MTS Mathlaul Anwar Lampung, kepala sekolah wajib mengusahakan keuangan agar kebutuhan akan sarana media pembalajaran terpenuhi. Begitupun untuk memenuhi kebutuhan SDM yang telah disampaikan diatas, pihak sekolah harus menyediakan anggaran yang mencukupi. Kebutuhan SDM akan Penerapan 
Media Pembelajaran Berbasis Teknologi Informasi dan Komunikasi (TIK) di MTS Mathlaul Anwar Lampung dapat diangkat menjadi karyawan atau bersifat kontrak selama pelaksanaan pembangunan atau pengembangan Penerapan Media Pembelajaran Berbasis Teknologi Informasi dan Komunikasi (TIK) di MTS Mathlaul Anwar Lampung dikerjakan.

- Rencana strategi yang ditetapkan. Kepala sekolah bersama-sama dengan wakil kepala sekolah dan Tim TI membuat rencana strategis penerapan media pembelajaran berbasis TIK sebagai arah dan pedoman bagi Tim TI dalam merealisasikan nilai strategis yang ingin dicapai. Adapun nilai stragisnya adalah meningkatnya mutu layanan pembelajaran, meningkatnya mutu SDM guru dan Siswa, meningkatnya prestasi siswa.

- Kesiapan Guru dan Siswa. Guru selaku pengguna dari hadirnya Media Pembelajaran dengan Teknologi Informasi dan Komunikasi (TIK) di MTS Mathlaul Anwar Lampung harus mampu menggunakan media pembelajaran ini sebaik mungkin. Keterampilan dan kecerdasan guru terhadap media pembelajaran berbasis TIK ini menjadi salah satu kunci utama sukses tidaknya proses pembelajaran dikelas. Sehingga sekurh pendidik (guru) diharuskan mengikuti pelatihan penggunaan media pembelajaran sesuai SOP yang telah ditentukan. Sementara siswa yang juga dapat memanfaatkan media pembelajaran berbasis TIK ini, harus juga memahami penggunaan dari media pembelajaran berbasis TIK. Oleh karena itu sosialisasi, pelatihan dan pembuatan SOP merupakan sebuah kewajiban yang harus dilakukan oleh Tim TI dan harus diikuti oleh semua warga belajar yaitu guru dan siswa.

- Rancangan atau desain Materi/Slide Pembelajaran. Agar proses pembelajaran menarik dan menyenangkan, maka Tim TI khususnya bidang desain grafis harus merancang materi pembelajaran semenarik mungkin. Materi pembelajaran yang didesain dikolaborasikan dengan tampilantampilan visual dan video yang menarik, atraktif dan itneraktif disesuaikan dengan mata pelajaran dan materi pembelajaran yang diberikan. Dengan demikian akan tercipta antusiasme belajar dari siswa yang pada akhirnya akan mewujudkan siswa yang cerdas dan berprestasi.

- Fasilitas Penunjang untuk Pembelajaran. Selain media pembelajaran berbasis TIK, berbagai fasilitas pembelajaran lainnya penting dihadirkan sebagai pelengkap dan pendukung proses pembelajaran dikelas. Oleh karenanya dalam Penerapan Media Pembelajaran Berbasis Teknologi Informasi dan Komunikasi (TIK) di MTS Mathlaul Anwar Lampung, kepala sekolah, wakil kepala sekolah, Tim TI dan guru wajib menghadirkan fasilitas pembelajaran lainnya seperti: alat peraga untuk simulasi materi pembelajaran, laptop, pointer, speaker nirkabel, gambar-gambar manual dan lain-lain.

Demikian secara singkat, peneliti sebagai evaluator memberikan evaluasi masukan (Input evaluation) terhadap Penerapan Media Pembelajaran Berbasis Teknologi Informasi dan Komunikasi (TIK) di MTS Mathlaul Anwar Lampung. 
3. Evaluasi Proses (Proccess Evaluation) Terhadap Penerapan Sistem Pembelajaran Berbasis Teknologi Informasi dan Komunikasi (TIK) Pada MTS Mathlaul Anwar Lampung.

“Evaluasi proses merupakan hasil dari penilaian terhadap data yang telah dikumpulkan dalam praktik pelaksanaan program. Intinya evaluasi proses untuk memahami dan mengetahui berbagai rencana yang telah diterapkan dan komponen apa yang perlu diperbaiki. Evaluasi proses mengungkap pertanyaan tentang "apa" (what) kegiatan yang dilakukan dalam program, (who) siapa personil yang ditugaskandalam melaksanakan sebuah program, (when) kapan pelaksanaan sebuah program selesai. Evaluasi proses dilakukan untuk memastikan sejauhmana keberhasilan setiap kegiatan yang dilaksanakan didalam suatu program". Arikunto dan Jabar dalam Ananda R., Rafida T (2017:46-47).

Berdasarkan teori diatas, evaluasi proses terhadap Penerapan Media Pembelajaran Berbasis Teknologi Informasi dan Komunikasi (TIK) di MTS Mathlaul Anwar Lampung dapat dijabarkan sebagai berikut:

- Apa kegiatan yang dilakukan (what)?. Adanya kegiatan yang dilakukan adalah adanya pembangunan Media Pembelajaran Berbasis Teknologi Informasi dan Komunikasi (TIK) di MTS Mathlaul Anwar Lampung. Evaluasi terhadap kegiatan ini adalah tidak tepatnya jadwal implementasi dengan kenyataan di lapangan. Pembangunan media pembelajaran berbasis TIK yang semestinya dapat diselesaikan dalam waktu tiga bulan, mundur menjadi hampir empat bulan. Selanjutnya kegiatan sosialisasi dan pelatihan terhadap guru dan siswa hanya diikuti oleh beberapa guru dan siswa. Dalam penerapannya dikelas, meskipun sudah diberikan Standar operasional prosedur (SOP) penggunaan media pembelajaran berbasis TIK, tidak sedikit berbagai kendala dan masalah terjadi, seperti kurangnya pemahaman guru terhadap media pembelajaran TIK, kesulitan guru dalam memperbaiki kesalahan-kesalahan yang sederhana, media pembelajaran yang kurang maksimal seperti komputer yang lambat, sound system, mic dan speaker yang kurang jelas atau bahkan tidak bunyi, kurangnya pencahayaan lcd projector dan permasalahan serta kendala lainnya. Semua masalah dan kendala ini bersumber dari kesiapan SDM, terbatasnya sarana dan media pembelajaran serta minimnya anggaran yang tersedia. Dari sisi pengawasan, kepala sekolah, Wakil Kepala Sekolah dan Tim TI tidak mempunyai agenda yang jelas dalam pemantauan jalannya proses pembelajaran menggunakan TIK.

- Who. Siapa personil yang ditugaskan dalam sebuah program?. Dalam penerapan media pembelajaran berbasis TIK ini, tentu Tim TI sebagai penanggungjawab dalam pembangunan dan pengembangannya.oleh karenanya Tim TI wajib merancang sebaik, seefektif dan seefisien mungkin sesuai harapan. Namun pada keyataannya masih terdapat berbagai kesalahan dan kekurangan disana-sini, diantaranya: waktu pembuatan yang lambat, tampilan slide materi pembelajaran yang kurang menarik, ketersediaan media pembelajaran yang minim. 
Selanjutnya didalam kelas, guru merupakan penanggungjawab dalam penerapan media pembelajaran berbasis TIK ini. pada kenyataannya proses pembelajaran berbasis TIK diruang kelas ini masih banyak kendala dan masalah hal ini dikarenakan ketidakfahaman guru terhadap media pembelajaran TIK dan tidak ikut sertanya guru dalam sosialisasi dan pelatihan media pembelajaran berbasis TIK. Atas dasar itu, evaluasi terhadap orang/bagian yang terlibat didalam pembangunan dan pelaksanaan penerapan media pembelajaran berbasis TIK ini harus segera dilakukan oleh MTS Mathlaul Anwar Lampung.

- Kapan (when) kegiatan akan selesai?. Perancangan penerapan media pembelajaran berbasis TIK ini direncanakan selesai dalam waktu tiga bulan, namun kenyataannya mundur menjadi hampir empat bulan. Hal ini terjadi karena berbagai kendala diantaranya adalah ketidaksiapan SDM yang sesuai dengan bidangnya, dan keterbatasan anggaran.

Dalam evaluasi proses, kegiatankegiatan penerapan media pembelajaran berbasis TIK yang dijadikan fokus evaluasi adalah terhadap kegiatan persiapan, kegiatan pengadaan SDM dan media pembelajaran, pembangunan/ perancangan, kegiatan pelatihan dan sosialisasi, kegiatan pembelajaran dikelas dan kegiatan pengawasan. dari kegiatan-kegiatan diatas ditemukan berbagai kegiatan yang masih terdapat banyak kendala sehingga penerapan media pembelajaran berbasis TIK di MTS Mathlaul Anwar Lampung belum sesuai harapan.

\section{Evaluasi Produk (Product Evaluation)} Terhadap Penerapan Sistem Pembelajaran Berbasis Teknologi Informasi dan Komunikasi (TIK) Pada MTS Mathlaul Anwar Lampung. Menurut Tayibnapis dalam Ananda R., Rafida T (2017:47-49) “Suatu evaluasi produk berfungsi membantu memberikan keputusan selanjutnya, baik berkenaan dengan hasil yang telah dicapai maupun apa yang dilakukan setelah program itu berjalan. Stufflebeam dalam Ananda R., Rafida T (2017:47) memperluas makna evaluasi product menjadi impact evaluation (evaluasi pengaruh), effectiveness evaluation (evaluasi keefektifan), sustainability evaluation (evaluasi keberlanjutan), dan transportability evaluation (evaluasi transformasi).

Bercermin dari teori diatas, Evaluasi Produk (Product Evaluation) yang dilakukan peneliti sebagai evaluator terhadap Penerapan Sistem Pembelajaran Berbasis Teknologi Informasi dan Komunikasi (TIK) Pada MTS Mathlaul Anwar Lampung dapat diuraikan sebagai berikut:

- Impact evaluation (evaluasi pengaruh). Dari temuan dan analisis yang dilakukan terhadap hasil penelitian yang dilakukan terhadap penerapan media pembelajaran berbasis TIK ini terdapat beberapa pengaruh diantaranya: 1) meningkatnya mutu layanan pembelajaran dikelas, meningkatnya mutu SDM guru dan siswa khususnya dibidang teknologi informasi dan komunikasi (TIK), meningkatnya prestasi siswa. Namun demikian pengaruh yang dirasakan masih sangat jauh dari apa yang menjadi harapan sekolah. Berbagai persiapan yang serba kurang, ketersediaan SDM bidang TIK yang sangat terbatas, dan media 
pembelajaran yang minim menjadi faktor kendala kurangnya pengaruh positif dari penerapan media pembelajaran berbasis TIK. hal ini harus menjadi perhatian pihak sekolah, bagaimana kedepan pengaruh positif dari penerapan media pembelajajaran berbasis TIK ini dapat dirasakan signifikan.

- Effectiveness evaluation (evaluasi keefektifan). Dibandingkan dengan media pembelajaran manual seperti menggunakan white board, penerapan media pembelajaran berbasis TIK tentu dapat dirasakan efektifitasnya. Ketersediaan kurikulum pembelajaran didalam komputer yang berbasis jaringan tentu memudahkan warga belajar (guru dan siswa) dalam proses pembelajarannya. Hal ini juga terjadi di MTS Mathlaul Anwar Lampung. Guru dan siswa sangat mudah melaksanakan proses pembelajaran dengan berbagai tampilan materi pembelajaran yang menarik baik berupa teks, gambar maupun video. Namun demikian yang perlu dievaluasi adalah keterbatasan kemampuan sdm guru dalam proses pembelajaran menggunakan sarana TIK menjadi kendala efektifitas penerapannya. Tidak sedikit guru yang membutuhkan waktu lama dalam mengaktifkan dan menggunakan media pembelajaran TIK, sehingga pelaksanaan pembelajaran yang terbatas waktunya menjadi kurang efektif. Selain itu keterbatasan kemampuan hardware (perangkat komputer) berkenaan dengan spesifikasi dan konfigurasi yang kurang maksimal turut memperlambat proses pembelajaran dikelas.

- Sustainability evaluation (evaluasi keberlanjutan). Evaluasi terhadap Penerapan Sistem Pembelajaran
Berbasis Teknologi Informasi dan Komunikasi (TIK) Pada MTS Mathlaul Anwar Lampung harus terus dilakukan. Berbagai aspek evaluasi dapat dilakukan terus secara berkala dilakukan baik evaluasi terhadap prosedur atau metode, evaluasi terhadap teknis, evaluasi terhadap SDM, sarana, media pembelajaran, media pendukung pembelajaran dan evaluasi terhadap aspek-aspek lainnya. Evaluasi keberlanjutan ini dilakukan untuk menemukan berbagai kendala dan kekurangan yang terjadi selama implementasi media pembelajaran berbasis TIK ini diterapkan.

- Transportability evaluation (evaluasi transformasi). Bentuk evaluasi ini dilakukan sebagai upaya untuk pengembangan Penerapan Sistem Pembelajaran Berbasis Teknologi Informasi dan Komunikasi (TIK) Pada MTS Mathlaul Anwar Lampung. Dengan adanya evaluasi trasnformasi, berbagai pengembangan penerapan media pembelajaran berbasis TIK dapat dilakukan sesuai dengan perkembangan jaman, perkembangan teknologi informasi dan komunikasi dan dalam rangka menjawab kebutuhan pengguna. Bentuk evaluasi transformasi terhadap penerapan mendia pembelajaran dapat berupa peningkatan kapasitas SDM melalui berbagai pelatihan, pendidikan formal, sertifikasi kompetensi dan bentuk lainnya. Bentuk evaluasi transformasi juga dapat berupa udate dan upgrade hardware dan software media pembelajaran sesuai perkembangan jaman dan bentuk evaluasi transformasi lainnya seperti perbaikan sistem pembelajaran, prosedur 
pembelajaran, perbaikan materi pembelajaran, tampilan materi pembelajaran, dll.

Merujuk pada teori yang dikemukakan Sudjana dan Ibrahim dalam Ananda R, Rafida T (2017:48), evaluasi proses dimaknai sebagai "sebuah kegiatan strategi dan penggunaan fasilitas, modal, dan bahan di dalam kegiatan nyata di lapangan, komponen proses meliputi kegiatan pembelajaran, pembimbingan, dan pelatihan". Dari teori diatas, jelaslah bahwa segala bentuk penggunaan fasilitas, anggaran, sarana, perlengkapan dan peralatan pada kegiatan penerapan media pembelajaran berbasis TIK di MTS Mathlaul Anwar Lampung yang dimulai dari tahapan perencanaan, pengorganisasian, pelaksanaan sampai dengan pengawasan perlu dievaluasi sebagai bentuk perbaikan dan peningkatan media pembelajaran berbasis TIK dimasa yang akan datang. Bentuk-bentuk evaluasi yang dilakukan mengacu kepada teori evaluasi program menurut Stufflebeam dalam Ananda R., Rafida T (2017:47) yang terdiri dari: 1) impact evaluation (evaluasi pengaruh), 2) effectiveness evaluation (evaluasi keefektifan), 3) sustainability evaluation (evaluasi keberlanjutan), dan 3) transportability evaluation (evaluasi transformasi).

\section{KESIMPULAN}

Teknologi Informasi dan Komunikasi (TIK) merupakan media yang sangat baik digunakan untuk membantu proses pembelajaran disekolah. Dengan Teknologi Informasi dan Komunikasi (TIK), proses pembelajaran akan lebih menarik, menyenangkan, efisien dan efektif. MTS Mathlaul Anwar Lampung adalah salah satu Sekolah yang memanfaatkan Teknologi Informasi dan Komunikasi (TIK) sebagai media pembelajaran dikelas. MTS
Mathlaul Anwar Lampung telah berhasil menerapkan Media pembelajaran berbasis Teknologi Informasi dan Komunikasi dengan menggunakan fungsi-fungsi manajemen terry yang dalam pembangunannya dimulai dari tahapan perencanaan, pengorganisasian, pelaksanaan dan pengawasan. Dalam istilah manajemen terdiri dari: Planning, Organizing, Actuating dan Controlling yang selanjutnya dikenal dengan POAC.

Pada tahapan perencanaan kegiatan yang dilakukan adalah rapat/pertemuan, pembuatan visi, misi, maksud dan tujuan penerapan media pembelajaran berbasis TIK, dan merumuskan rencana strategis serta nilai strategis yang ingin dicapai. Selanjutnya pada tahap pengorganisasian kegiatan yang dilakukan adalah pembentukan Tim IT berikut Surat Tugasnya (ST) dengan tugas utamanya adalah melakukan pembangunan Media Pembelajaran Berbasis Teknologi Informasi dan Komunikasi di MTS Mathlaul Anwar Lampung. Pada tahapan ketiga adalah pelaksanaan penerapan sistem pembelajaran berbasis teknologi informasi dan komunikasi (TIK) ini, kegiatan utama pada tahap ini adalah implementasi pembelajaran berbasis Teknologi Informasi dan Komunikasi (TIK) dikelas oleh guru dan siswa. Pada tahapan fungsi manajemen terakhir ini yaitu tahap pengawasan, kegiatan yang dilakukan oleh kepala sekolah, wakil kepala sekolah dan Tim TI adalah memantau jalannya pelaksanaan penerapan sistem pembelajaran berbasis teknologi informasi dan komunikasi (TIK) dikelas dengan mengakomodir berbagai kekurangan, kesalahan, keluhan dan masukan dari guru dan siswa selama berlangsungnya pembelajaran berbasis TIK dikelas.

Hasil Evaluasi program yang peneliti lakukan pada tahap Evaluasi konteks peneliti menguraikan tentang analisis SWOT (Strength, Weakness, Opportunity and Threat) yang dimiliki oleh MTS Mathalul Anwar Lampung. Analisis inilah 
yang wajib dijadikan sebagai landasan dalam penerapan media pembelajaran berbasis TIK. selanjutya pada tahap evaluasi masukan (Input Evaluatioan) peneliti memberikan evaluasi tentang kondisi SDM, kondisi sarana dan prasarana, kemampuan keuangan (anggaran), pentingnya rencana strategi yang ditetapkan, Kesiapan Guru dan Siswa sebagai pengguna utama, evaluasi terhada rancangan materi pembelajaran dan terakhir evaluasi terhadap fasilitas pembelajaran lainnya. Sementara pada evaluasi proses (Proccess Evaluation), peneliti memberikan evaluasi terhadap berbagai kegiatan yang dilakukan selama pembangunan, evaluasi terhadap siapa saja yang terlibat dalam pembangunan media pembelajaran ini dan evaluasi terhadap waktu kegiatan. Evaluasi terakhir terhadap evaluasi produk (Product Evaluation), peneliti melakukan evaluasi terhadap dampak atau pengaruh yang ditimbulkan baik terhadap mutu layanan maupun terhadap peningkatan SDM guru dan Siswa, selanjutnya peneliti mengevalusi sejauhmana efektifitas dan efesiensi yang ditimbulkan dari penerapan media pembelajaran berbasis TIK ini. Pada evaluasi produk ini, peneliti memberikan arahan akan pentingnya melakukan keberlanjutan evaluasi dan melakukan transformasi untuk pengembangan penerapan media pembelajaran berbasis TIK kedepan.

\section{DAFTAR PUSTAKA}

Ananda, R., Rafida, T., \& Wijaya, C. (2017). Pengantar evaluasi program pendidikan.

Awaluddin, A., \& Hendra, H. (2018). Fungsi manajemen dalam pengadaan infrastruktur pertanian masyarakat di desa watatu kecamatan banawa selatan kabupaten donggala. Publication, 2(1), 1-12.
Bhakti, Y. B. (2017). Evaluasi program model CIPP pada proses pembelajaran IPA. JIPFRI (Jurnal Inovasi Pendidikan Fisika Dan Riset Ilmiah), 1(2), 75-82.

Marlina, S. (2013). Pengembangan Perangkat Pembelajaran Sikap Sosial Multikultural Melalui Permainan Puzzle pada Pendidikan Anak Usia Dini Studi di Tk Mariana Padang. Pedagogi: Jurnal Ilmu Pendidikan, 13(1), 40-46.

Horwath, D., Yuan, W., Check, J. H., Summers-Chase, D., \& Swenson, K. (2006). P-290. Fertility and Sterility, 86(3)

Mukhlisin. (2015). Sistem Informasi Manajemen Berbasis Teknologi Informasi dan Komunikasi Dalam Peningkatan Mutu Layanan Pendidikan dan Latihan Profesi Guru (PLPG), (Studi Kasus Pada MTsN 1, MTsN 2, MTs Pancasila di Lingkungan Kementrian Agama Kota Bengkulu (Pertama). Perpustakaan Pascasarjana Uninus, Bandung.

Musfiqon. (2012). Metodologi Penelitian Pendidikan. Jakarta: PT Prestasi Pustakaraya.

Nasution. (1992). Metode Penelitian Naturalistik Kualitatif. Bandung: Tarsito.

Sugiyono. (2011). Metode Penelitian Kuantitatif, Kualitatif dan R\&D. Bandung: Alfabeta.

Supadi, S. (2017). Evaluasi Program Mutu Berbasis Sekolah (Mmbs) di SMA N 61 Unggulan Jakarta Timur (Pendekatan Evaluasi Berdasarkan Model Cipp). Perspektif Ilmu Pendidikan, 31(2), 82-88.

Wijaya, C., \& Rifa'i, M. (2016). Dasar-dasar manajemen: mengoptimalkan pengelolaan organisasi secara efektif dan efisien.

Wijayanti, N. I., Yulianti, R., \& Wijaya, B. (2019). Evaluasi Program Pendidikan Pemakai Dengan 
Publipreneur Polimedia: Jurnal Ilmiah Jurusan Penerbitan Politeknik Negeri Media

Kreatif

Vol.9, No. 1, Juni 2021 hal. 53-71

Model CIPP di Perpustakaan

Fakultas Teknik UGM. Tik Ilmeu:

Jurnal Ilmu Perpustakaan dan

Informasi, 3(1), 37-66. 